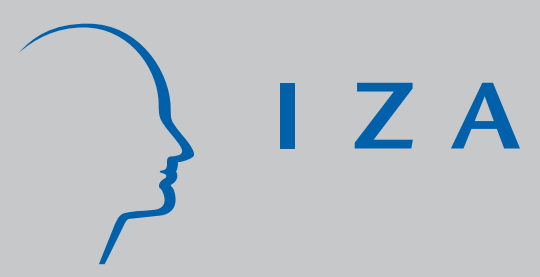

IZA DP No. 489

Employment Patterns of Husbands and Wives and Family Income Distribution in Italy (1977-1998)

Daniela Del Boca

Silvia Pasqua

April 2002 


\title{
Employment Patterns of Husbands and Wives and Family Income Distribution in Italy (1977-1998)
}

\author{
Daniela Del Boca \\ University of Turin and IZA, Bonn \\ Silvia Pasqua \\ University of Turin
}

Discussion Paper No. 489

April 2002

\author{
IZA \\ P.O. Box 7240 \\ D-53072 Bonn \\ Germany \\ Tel.: +49-228-3894-0 \\ Fax: +49-228-3894-210 \\ Email: iza@iza.org
}

This Discussion Paper is issued within the framework of IZA's research area The Future of Labor. Any opinions expressed here are those of the author(s) and not those of the institute. Research disseminated by IZA may include views on policy, but the institute itself takes no institutional policy positions.

The Institute for the Study of Labor (IZA) in Bonn is a local and virtual international research center and a place of communication between science, politics and business. IZA is an independent, nonprofit limited liability company (Gesellschaft mit beschränkter Haftung) supported by the Deutsche Post AG. The center is associated with the University of Bonn and offers a stimulating research environment through its research networks, research support, and visitors and doctoral programs. IZA engages in (i) original and internationally competitive research in all fields of labor economics, (ii) development of policy concepts, and (iii) dissemination of research results and concepts to the interested public. The current research program deals with (1) mobility and flexibility of labor, (2) internationalization of labor markets, (3) welfare state and labor markets, (4) labor markets in transition countries, (5) the future of labor, (6) evaluation of labor market policies and projects and (7) general labor economics.

IZA Discussion Papers often represent preliminary work and are circulated to encourage discussion. Citation of such a paper should account for its provisional character. A revised version may be available on the IZA website (www.iza.org) or directly from the author. 


\title{
ABSTRACT \\ Employment Patterns of Husbands and Wives and Family Income Distribution in Italy (1977-1998) ${ }^{*}$
}

The pattern of employment among men and women has changed remarkably over the past decades. While the employment rate of women has risen, that of men has continued to decline. Disproportionate growth in the participation in the labor market of women with highincome husbands has heightened concerns that wives' earnings may increase income inequality among married couples. Questions about the implications for income distribution have also been raised, especially in countries like Italy, the UK, and the US, where more noticeable growth of income inequality during the last decade has accompanied changes in employment levels. In this paper we attempt to measure the impact of the changes of women and men's employment patterns on the distribution of income among Italian households. Using microdata from the Historical Archive of the Bank of Italy Survey of Household Income and Wealth (SHIW), a repeated cross-sectional survey that covers the period 1977-1998, we examine the impact of employment changes on inequality in family income distribution and how this relationship has changed over time and across regions. Our preliminary results show that the increase in the employment of women during the period of observation had the effect of reducing inequality in family incomes, while the decline in men's employment had the opposite effect. The equalizing impact of wives' work on income inequality has become increasingly important over time and has been greater among Northern households. Especially since the mid-nineties, wives' earnings have reduced inequality in as much as the distribution of income would have been less equal in their absence. More conclusive results could be achieved by analyzing a more structural approach where the labor supply of husbands and that of wives are determined simultaneously.

JEL Classification: D31, J22

Keywords: labor market participation, family income inequality

\author{
Daniela Del Boca \\ Department of Economics \\ University of Turin \\ Via Po 53 \\ 10124 Torino \\ Italy \\ Tel.: +39-11-6702 704 \\ Fax: +39-11-6702 762 \\ Email: daniela.delboca@unito.it
}

\footnotetext{
${ }^{*}$ We gratefully acknowledge support from Compagnia di San Paolo and from the Ministry of University and Scientific Research (MURST).
} 


\section{Introduction}

The pattern of employment among men and women has changed remarkably over the past several decades. While the employment rate of men decreased in most advanced countries between 1973 and 1998, the employment rate of women has increased markedly, with most of the change being attributable to changes in the patterns of labor market activity by married women. Figures 1 and 2 show the data for female and male employment rates for some European countries. All these countries show similar patterns.

\section{Figure 1}

Female participation rate in European countries

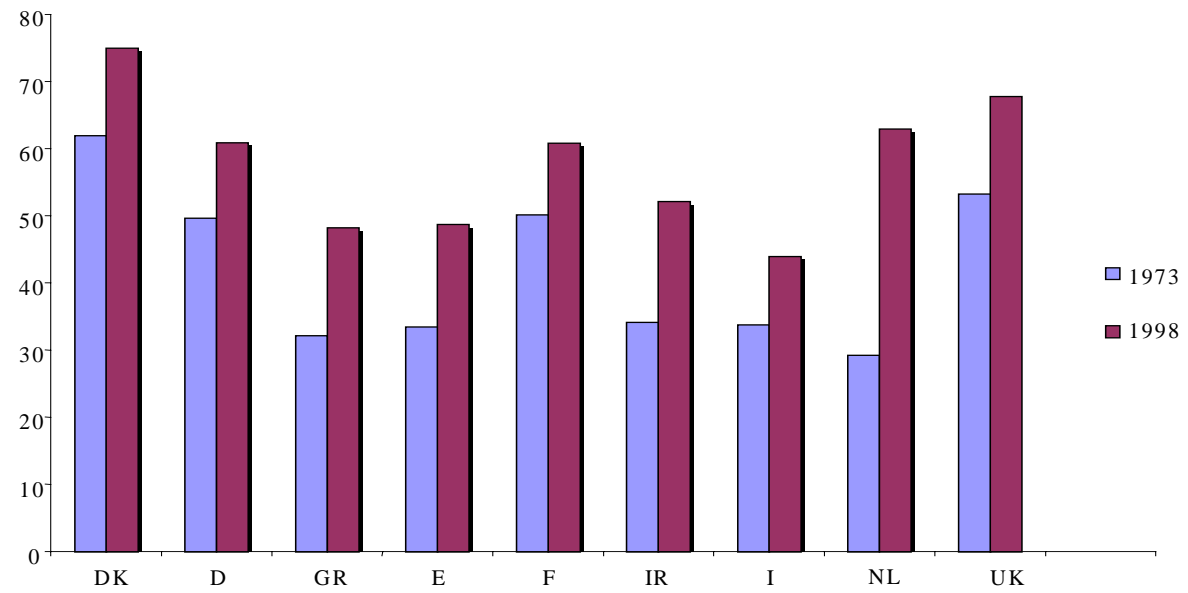

Source: OECD, Employment Outlook, 1999

Figure 2

Male participation rate in European countries

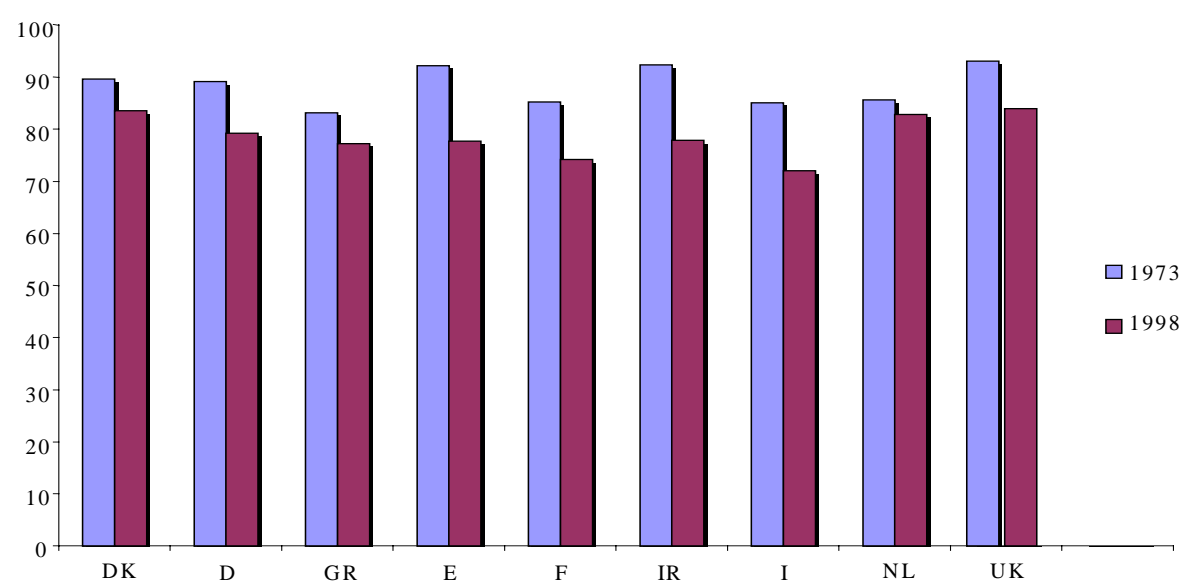

Source: OECD, Employment Outlook, 1999 
These changes in labor market participation have brought changes in the contributions of wives and husbands to family income. Questions have arisen about the effect that changes in the employment patterns of wives and husbands have had on family inequality.

Do changes in income inequality matter? There are several reasons why one might care about changes in income distribution. One is the possible relationship between inequality and macroeconomic growth. Within the framework of endogenous growth theories, a number of authors have provided evidence that an unequal distribution of income might ultimately affect economic growth, mainly through the channels of education, access to capital markets, and political and economic mechanisms (e.g. Bénabou 1996; Alesina and Rodrik, 1994). Increasing poverty (especially of the younger cohorts) and diffusion of low paid jobs have also evolved in parallel with income inequality (Brandolini, Cipollone and Sestito, 2000).

The link between wives' employment and inequality is documented in Figure 3, where, for different European countries, the percentage of working women and the level of inequality (measured by the squared coefficient of variation) are shown in the same diagram. The data show that countries with higher female employment rates are also characterized by more equal household income distributions. Only the UK and Portugal seem to have high percentages of working women and high inequality.

Figure 3

\section{Women's work and inequality in income distribution in Europe (1995)}

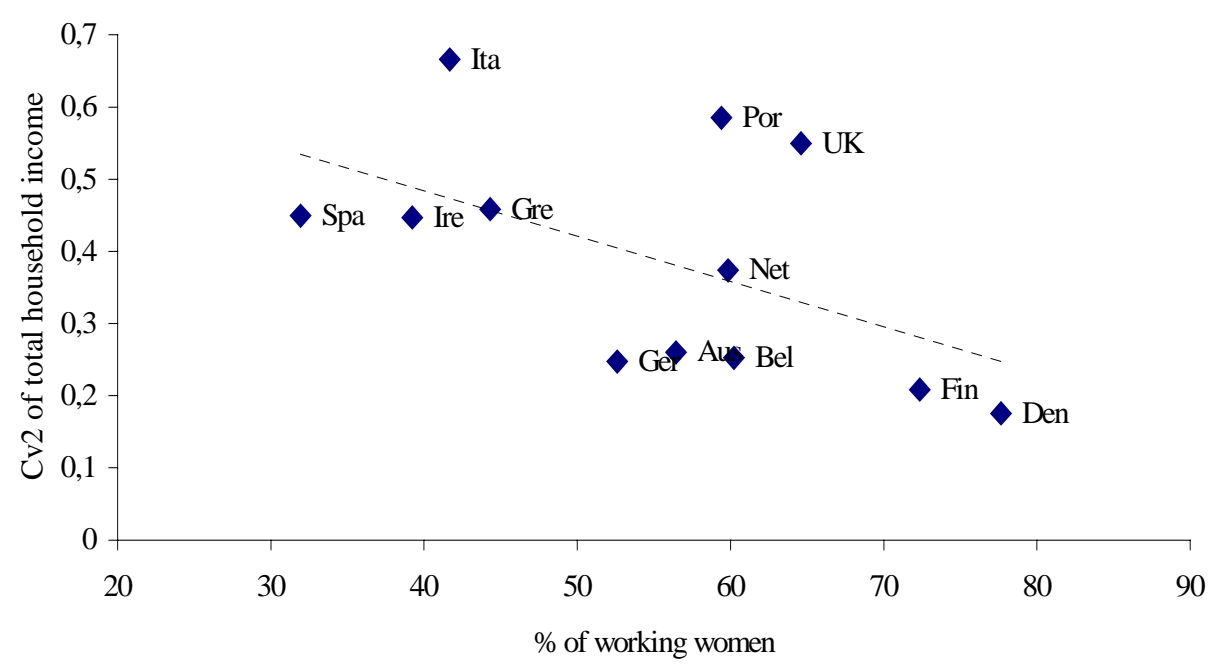

Source: Pasqua (2001) using ECHP dataset 
Figure 4

Inequality and women's employment rate in Italian regions

1977

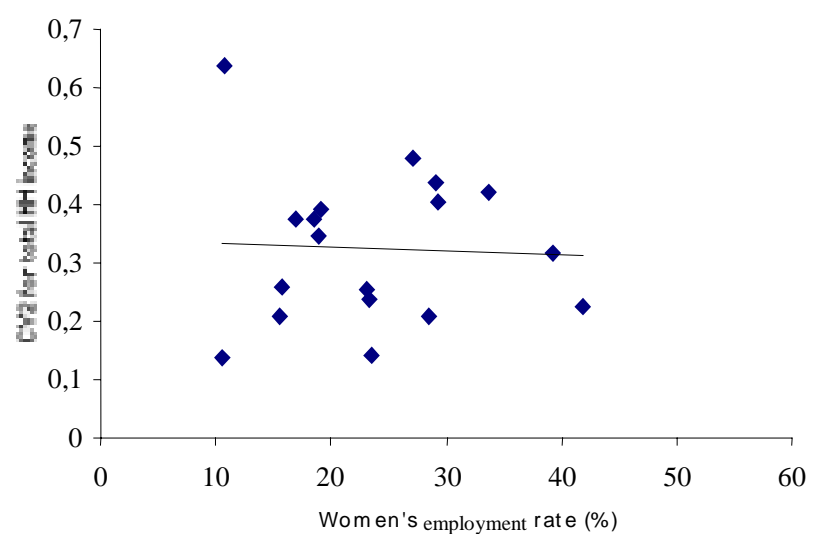

1984

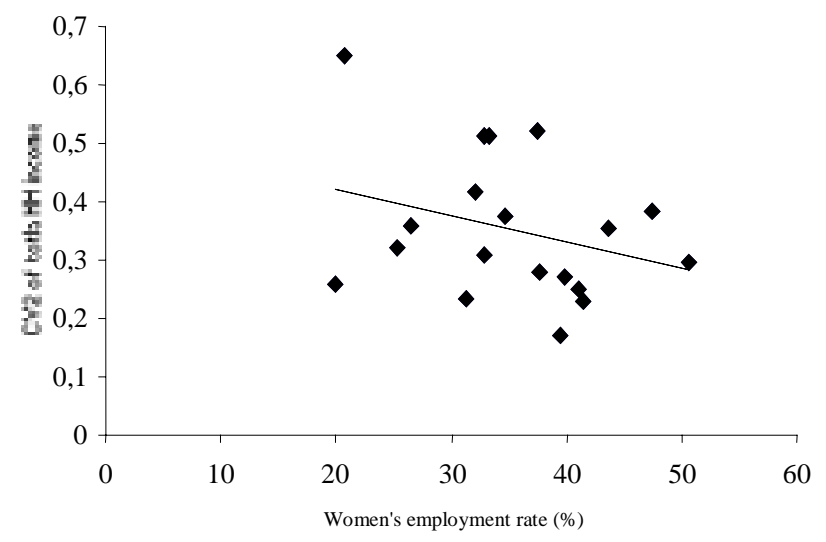

1993

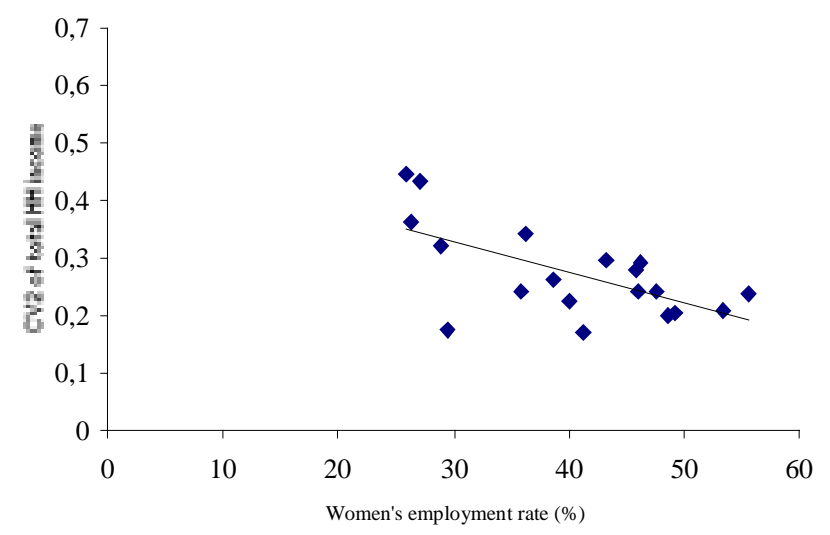

Source: authors' elaboration using SHIW dataset
1980

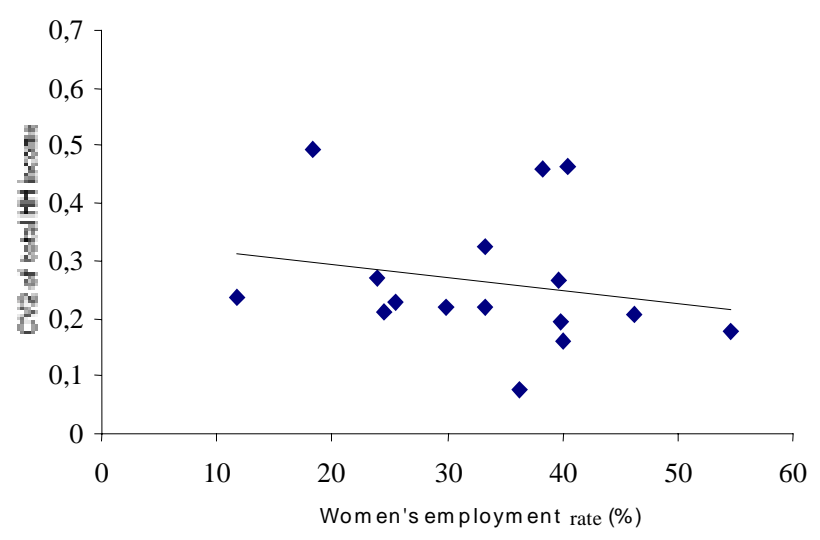

1989

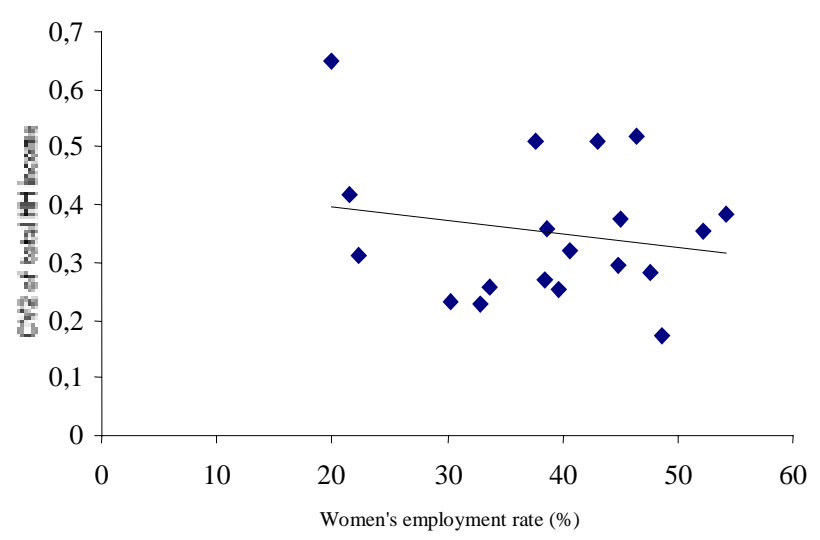

1998

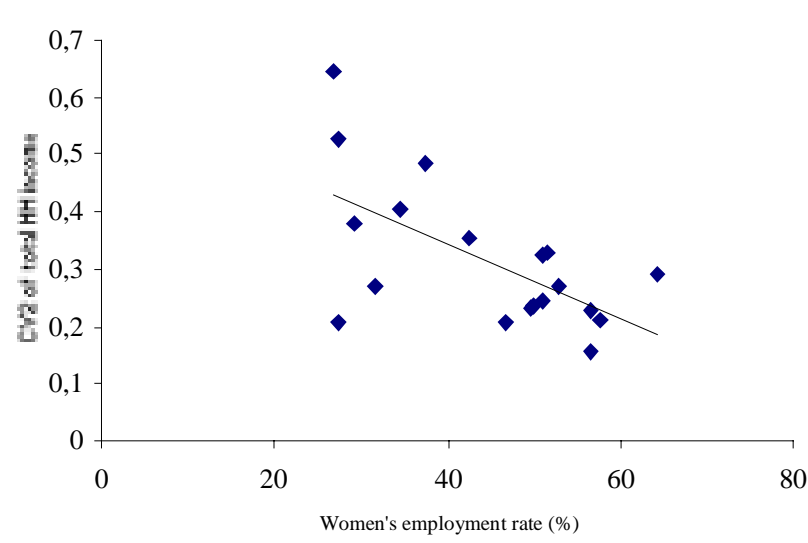


A negative relationship between women's employment and income inequality emerges also in Italian regions. In regions where women work more, inequality is lower. Figure 4 shows that the relationship changed overtime, becoming stronger.

The effect of women's work on income inequality depends on the type of women who enter in the labor market. If the employment of women married to husbands with lower earnings increases relatively more, this would contribute to lower income inequality. If instead it is the employment rate of wives whose husbands have high earnings to increase relatively more, this produces an increase in the polarization of household income distribution. In other words the rise of wives employment would lead to a contemporaneous growth of households where both spouses work and a rise of households where nobody works.

In this paper we intend to measure the impact in the last two decades of the changes in employment patterns of wives and husbands on the distribution of family income among households where both spouses are present and in working age, with a particular focus on the differences between Northern and Southern regions. A remarkable difference between North and South still exists both in the characteristics of the labor market and in the social service system. While in the North there are greater opportunities for part-time activities (which, especially for women, enable work and family-care activities to be combined), in the Southern regions these opportunities are more limited. Moreover, in regards to the social service system, remarkable differences exist in the availability of childcare for children under the age of three in the Northern and Southern regions. Public childcare facilities provide places for $25-30 \%$ of the $0-3$ year population in most regions of the North, while in the South only 1-2\% of pre-school children have access to kindergartens. The rigidity and limitations of public childcare services may have a negative impact on women's employment ${ }^{1}$.

To take these differences into account while examining changes in the contribution of husbands' and wives' earnings to inequality during the 1977-1998 period, we also consider the different impact of men's and women's work in the North and in the South of the country. 


\section{The data}

In this paper we use microdata from the Historical Archive of the Bank of Italy Survey of Household Income and Wealth (SHIW), a repeated cross-sectional survey that covers the 19771998 period (for a historical description see Brandolini, 1999).

The archive includes the historical series of relevant variables related to household income and wealth, including income from work (as employees and self-employees), pensions, public transfers, income from real properties and the imputed rental income. It also includes interests on financial assets, net of interest paid on mortgages.

The use of this data set poses many problems in terms of the structure and quality of the survey (well addressed in Brandolini, Cipollone and Sestito, 2000; as well as in Brandolini and D'Alessio, 2000). Despite these problems ${ }^{2}$, the SHIW is the only source of individual data that collects demographic and labor market information on the individuals in the sample and that makes it possible to provide consistent measurements of changes in Italian income distribution.

Our sample includes only households in which both spouses are present and the wife is younger than 60. In Table A1 (in the Appendix) we report some descriptive statistics for our sample regarding area of residence, family size, husband's and wife's education, age and employment rates.

The demographic characteristics of the sample changed during the period. The proportion of households living the North decreased from 50.9 to $40.2 \%$, while the percentage of households living in the Center and the South increased (respectively from 19.1 to $21.5 \%$ and from 30 to 38.3\%). In fact, the Italian population between 1977 and 1998 increased by 2.5 per cent, but the increase was almost entirely concentrated in the South (given the higher fertility rate in these area).

Similarly to the other OECD countries, the data show an increase in the share of highly educated workers: the incidence of employees with high-school qualification increased from 19 to $45 \%$ among men, and from 22 to $43 \%$ among women. The percentage of graduate employees rose from 6 to $9 \%$ among both men and women.

In terms of household labor-market participation, the husbands' employment rate declined from 83.8 to $77.5 \%$, while the percentage of working wives increased from 25.7 to $44.3 \%$. At national level, the distribution of employment was sensitive to the state of the business cycle only in the case of men. On the contrary, the proportion of women workers seem to be more independent of the business cycle, continuing to grow during the two decades considered. However, as we will

\footnotetext{
${ }^{1}$ See Del Boca (2001) and Chiuri (2000) for an analysis of the impact of child care on women participation in the labor market.

${ }^{2}$ Mainly the patterns of non-response and the relatively small size of the survey.
} 
discuss in the following sections, there are considerable differences in the employment of women in the North and South of the country: while the employment pattern for men does not change much across regions, the employment of women in the South seems to be more responsive to the business cycle than in the North.

\section{Previous results}

The impact of the married wives' employment on income distribution depends in part on what factors motivate their decision to work. The increased number of opportunities (especially for highly educated women), the availability of jobs and social services that make it possible to reconcile family work with outside activities (services sector), and the need to respond to changes in the family's labor supply and income (especially for women in the lowest quintile groups of income distribution) seem to be the main factors in explaining the growth of female employment. Over the past twenty years, real wages have declined for less skilled men and the proportion of unemployed men has increased. As a consequence, the increased employment of wives in the labor force in recent years may reflect the need to offset the negative impact of their husbands' performance in the labor market.

Using US data, Lundberg (1985) found a small added worker effect ${ }^{3}$, and Ercolani and Jenkins (1999) reported a similar effect for British couples. In their analysis of Italian data, Del Boca, Locatelli and Pasqua, (2001), and Rossetti and Tanda (2000), on the contrary, report evidence of strong assortative mating: working women are more likely to be married to employed men with a higher level of education and higher incomes.

Del Boca, Locatelli and Pasqua (2000) in explaining women's decisions to work have analyzed the effect of variables describing economic constraints (husbands' income and employment status) taking into account variables related to family background (such as the working status of mothers) and variables related to environmental opportunities (such as the availability of childcare by region). They found that an important role is played by family background which affect women's attitudes to work. The response to the event of the husband losing his job is mediated by women attitudes, which are affected by whether or not other women in the family have worked in the past. An added worker effect is found in households in which the role of women in the labor market has been long accepted and considered more favorably. The result is consistent

\footnotetext{
${ }^{3}$ The added worker effect is the increase in the wife's participation in the labor market as a response to her husband's unemployment and low income.
} 
with previous studies (UK and France) that have explored the nature of the correlation between the participation of married women in paid work and the employment status and income of the husbands, controlling for family background (Molho and Elias, 1984; Barrere-Maurisson et al., 1985). This analysis is also coherent with models that analyze women's employment decisions in a framework where relative economic status comparisons with other women in the family are important (Neumark and Postlewhite, 1995).

Questions about the implications of women employment growth for income inequality has been raised mostly in studies analyzing US and UK, where more noticeable growth in income inequality has been recorded. Karoly and Burtless (1995) found that women's work has a disequalizing effect, increasing income inequality. Cancian et al. (1992) show that married women's work has instead an equalizing impact. In their work it is examined how the increasing labor force participation of wives have affected the level and the distribution of household earnings in the US during the seventies and the eighties. In his survey, Lam (1997) report how different studies have shown different results. Using ECHP (European Community Household Panel) data set, Pasqua (2001) found that wives' contribution to inequality in household income distribution is higher where female employment rate is lower. This means that where only highly educated women work, this has a disequalizing effect on family income distribution. If also relatively lower educated women enter the labor market, their earnings may help to reduce inequality. In fact, if the assortative mating effect dominates, we should expect a disequalizing impact of wives' work on the distribution of family income. On the contrary, if the added worker effect prevails, we would expect an equalizing effect since the employment of wives in lower income families reduces inequality.

Following this line we have attempted to measure the impact of these important changes in husbands and wives' employment patterns on income inequality considering temporal variation as well as regional differences.

\section{Employment and earnings of husbands and wives}

Our analysis focuses on the employment status, earnings and incomes of married couples during the 1977-1998 period. As has been shown in several studies, the Italian employment rate is among the lowest of all advanced countries both for men and for women. The Italian labor market is characterized by considerable rigidities, mainly related to the high costs of hiring and firing workers. This has a strong impact on employment patterns and indeed, for the period considered 
(which also includes a year of recession in 1993), we notice less remarkable changes in employment patterns than in other countries.

Our data show that the employment of married women aged less than 60 increased in Italy in the period 1977-1998 from 25.7 to $44.3 \%$, while in the South the increase was slightly lower : from 15.2 to $31 \%$ (see Figure 5).

Figure 5

\section{Employed married women (percentage)}

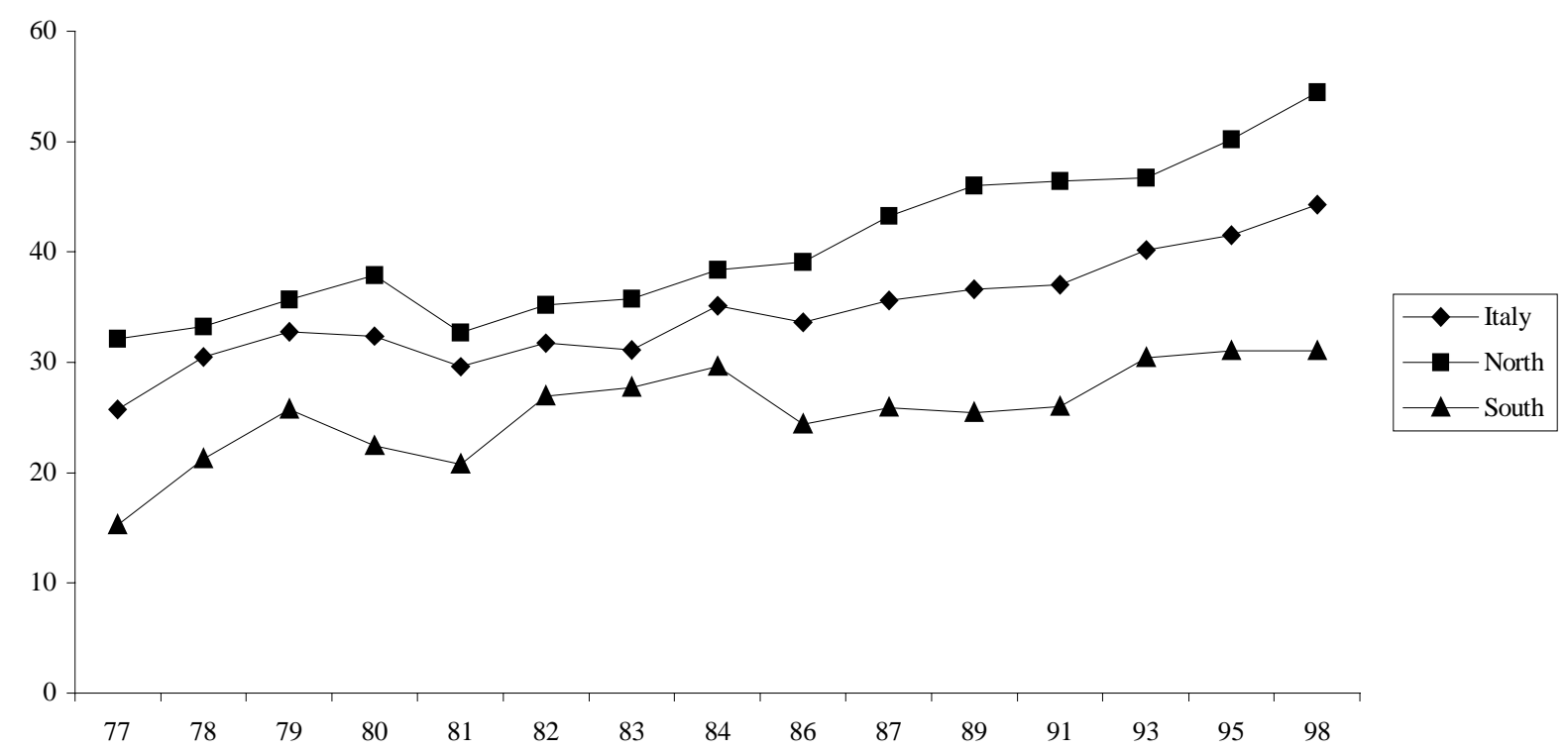

The data on unemployment rates among married women under 60 years of age also show that the unemployment rate has doubled over the last two decades. These figures, jointly with the employment data, indicate an increased propensity of married women to participate in the labor market.

During the same period, data on the employment of men indicate a decline from the late seventies to the mid-eighties and a growth that reaches its peak in 1987, before declining until the end of the nineties. During the last decade, employment rates of men decreased constantly in all regions until 1995. It then continued to decline in the Southern regions while remaining stable in the North (see Figure 6). 
If the pattern of employment of men does not change much from one region to another, the employment of women seems to be more responsive to the business cycle in the South than in the North.

Figure 6

\section{Employed married men (percentage)}

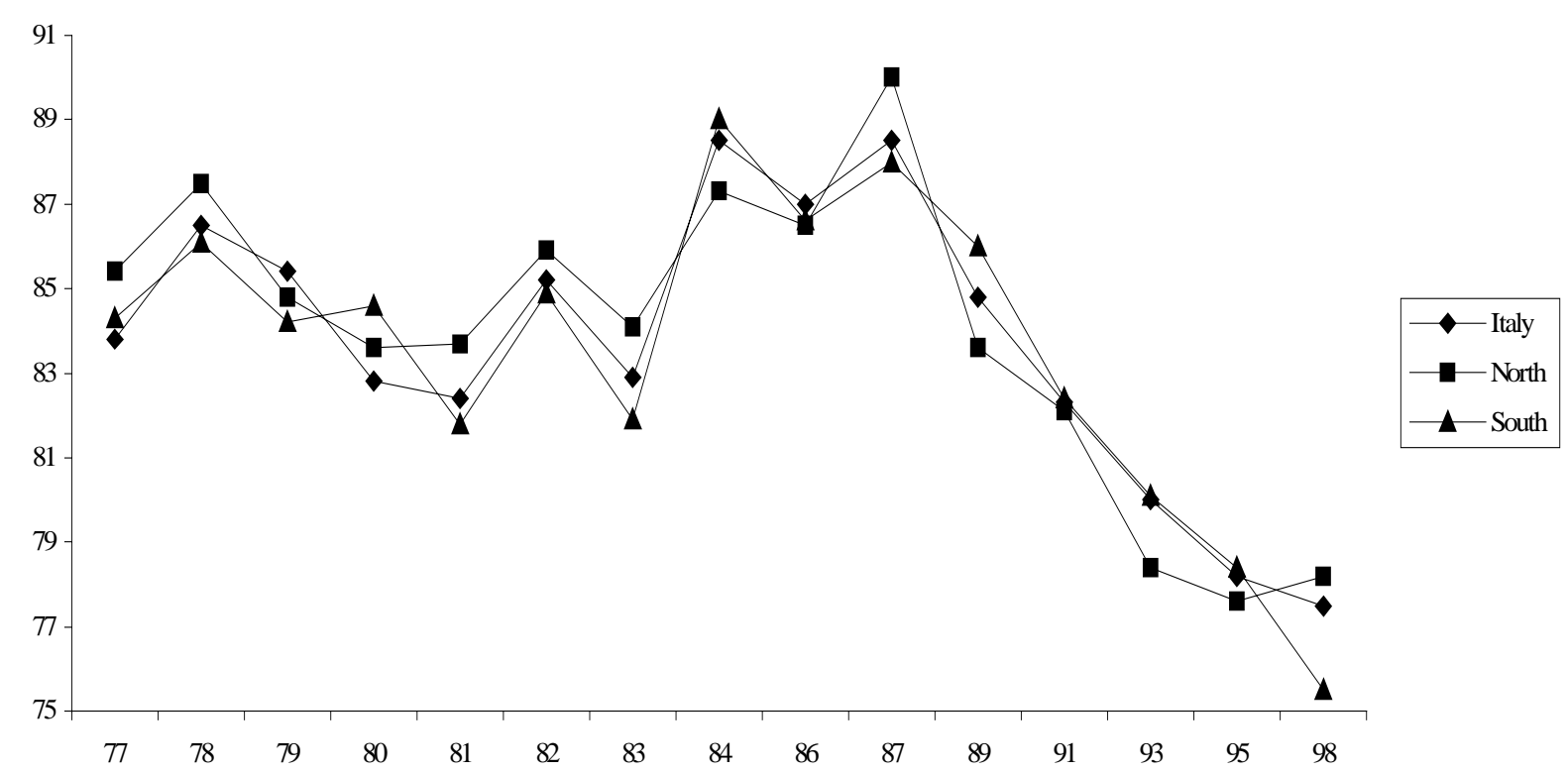

In order to analyze the relationship between husbands' and wives' employment and earnings, we first present some descriptive statistics regarding the relationship between the occupational status of husbands and wives. The following Table 1 shows the employment rates of women married to working and non-working men. The data indicate that the proportion of working women married to employed men increased from $28.7 \%$ in 1977 to $49.9 \%$ in 1998 , while the percentage of working women with an unemployed husband rose from 10.4 to $25.5 \%$ over the same period.

Table 1 shows also the same data for the Northern and Southern regions. The pattern is not different but, whereas in the North the number of women married to employed men increased from 36.4 to $62.7 \%$, in the Southern regions it rose only from 16 to $34.1 \%$. A much smaller difference 
appears between the proportion of women married to non-employed men in the North and in the South in all the years considered.

Table 1

Employment rates of wives (\%)

\begin{tabular}{lcccccc}
\hline & $\mathbf{1 9 7 7}$ & $\mathbf{1 9 8 0}$ & $\mathbf{1 9 8 4}$ & $\mathbf{1 9 8 9}$ & $\mathbf{1 9 9 3}$ & $\mathbf{1 9 9 8}$ \\
\hline & \multicolumn{7}{c}{ Italy } \\
\cline { 2 - 7 } All & 25.7 & 32.4 & 35.0 & 36.6 & 40.4 & 44.6 \\
Married to working men & 28.7 & 35.6 & 36.9 & 39.5 & 44.2 & 49.9 \\
Married to non-working men & 10.4 & 16.8 & 20.6 & 20.2 & 23.5 & 25.5 \\
\hline & \multicolumn{7}{c}{ North } \\
All & 32.2 & 38.0 & 38.4 & 46.1 & 46.8 & 54.5 \\
Married to working men & 36.4 & 42.5 & 41.6 & 50.4 & 54.6 & 62.7 \\
Married to non-working men & 7.5 & 15.3 & 16.7 & 23.9 & 18.2 & 24.7 \\
\hline \multirow{2}{*}{ All } & \multicolumn{7}{c}{ South } & & \\
Married to working men & 15.2 & 22.4 & 29.7 & 25.5 & 30.6 & 31.6 \\
Married to non-working men & 16.0 & 22.9 & 30.0 & 26.7 & 31.5 & 34.1 \\
\hline
\end{tabular}

Table 2 shows that the percentage of working wives increases when the husband's income increases. This is due both to assortative mating and to better opportunities that richer households have and that make it easier for women in the higher income groups to find a job. By itself this would lead to greater inequality.

The data desegregated by North and South show relevant regional differences in the employment rates of women in the different quintile groups of husbands' income distribution. In the North, in fact, in all years considered women who work more are those belonging to the second and third quintile groups of husbands' income distribution, while in the Southern the largest percentage of working women are in the highest quintile groups. It appears that, during the period of observation, the employment of women in the North was higher in households where husbands' earnings were higher and this may had the effect of reducing inequality, while in the South the employment rates of women higher in the highest quintile groups may had contribute to increase inequality. 
Table 2

Percentage of working wives by quintile of husband income distribution

\begin{tabular}{lccccc}
\hline & $\mathbf{1}^{\text {st }}$ & $\mathbf{2}^{\text {nd }}$ & $\mathbf{3}^{\text {rd }}$ & $\mathbf{4}^{\text {th }}$ & $\boldsymbol{5}^{\text {th }}$ \\
\hline & & & Italy & & \\
\cline { 2 - 6 } 1977 & 10.9 & 23.2 & 35.4 & 31.2 & 26.7 \\
1980 & 18.2 & 30.0 & 41.2 & 38.0 & 35.5 \\
1984 & 27.6 & 35.3 & 41.0 & 39.7 & 32.4 \\
1989 & 23.9 & 39.5 & 40.3 & 40.8 & 38.6 \\
1993 & 24.7 & 40.1 & 41.5 & 46.0 & 50.8 \\
1998 & 25.5 & 45.0 & 50.3 & 50.8 & 53.1 \\
\hline & & & North & & \\
1977 & 13.4 & 41.2 & 42.2 & 37.2 & 28.9 \\
1980 & 17.7 & 43.9 & 49.7 & 44.7 & 34.4 \\
1984 & 31.2 & 40.9 & 46.9 & 39.0 & 31.8 \\
1989 & 27.9 & 56.7 & 55.5 & 48.6 & 41.6 \\
1993 & 18.2 & 54.9 & 53.0 & 58.0 & 52.7 \\
1998 & 24.7 & 60.8 & 65.5 & 63.2 & 60.4 \\
\hline & & & South & & \\
1977 & 10.8 & 11.5 & 12.6 & 23.3 & 18.0 \\
1980 & 21.3 & 26.8 & 22.1 & 20.1 & 21.0 \\
1984 & 26.4 & 26.8 & 27.6 & 37.3 & 32.2 \\
1989 & 21.1 & 23.1 & 25.3 & 28.1 & 30.1 \\
1993 & 27.2 & 27.9 & 23.7 & 35.4 & 40.4 \\
1998 & 23.1 & 32.3 & 32.7 & 31.8 & 39.4 \\
\hline
\end{tabular}

Table 3 reports mean earnings of working wives classified by husbands' earnings quintile for Italy and disaggregated by North and South. Wives' earnings in real terms increased more in the lowest two and in the top quintile groups of husband income distribution. In the South the increase was greater in the lower quintile groups than in the higher ones. The greater increase in women's labor income in the lower quintile groups may have had an equalizing impact on household income distribution that could have compensated for the apparently unequalizing impact of assortative mating.

The data presented thus far suggest that wives' employment and earnings have become an increasingly important source of family income and that changes in wives' employment and earnings have varied substantially according to area of residence and husbands' earnings. 
Average earnings of working wives by quintile of husband income distribution (constant 1998 lire - thousands)

\begin{tabular}{lccccc}
\hline & $\boldsymbol{1}^{\text {st }}$ & $\mathbf{2}^{\text {nd }}$ & $\mathbf{3}^{\text {rd }}$ & $\mathbf{4}^{\text {th }}$ & $\boldsymbol{5}^{\text {th }}$ \\
\hline & \multicolumn{5}{c}{$\boldsymbol{I t a l y}$} \\
1977 & 13,105 & 11,970 & 16,379 & 19,031 & 21,142 \\
1980 & 14,946 & 13,011 & 18,251 & 19,746 & 23,244 \\
1984 & 14,875 & 15,866 & 19,908 & 20,334 & 26,005 \\
1989 & 22,038 & 19,948 & 23,730 & 25,414 & 28,535 \\
1993 & 18,664 & 15,007 & 21,096 & 22,686 & 28,347 \\
1998 & 21,280 & 17,327 & 19,970 & 22,105 & 26,597 \\
\hline & & & & \\
1977 & 14,562 & 15,217 & 18,496 & 20,067 & 21,786 \\
1980 & 18,939 & 16,503 & 19,991 & 21,119 & 21,642 \\
1984 & 15,606 & 16,903 & 20,751 & 20,336 & 24,382 \\
1989 & 22,209 & 20,603 & 24,557 & 26,306 & 29,635 \\
1993 & 19,466 & 17,897 & 21,916 & 22,726 & 29,471 \\
1998 & 22,244 & 19,421 & 20,928 & 24,252 & 28,240 \\
\hline & & & & \\
1977 & & & & & \\
1980 & 11,796 & 6,815 & 10,083 & 17,225 & 20,089 \\
1984 & 11,970 & 8,859 & 14,160 & 18,680 & 20,690 \\
1989 & 14,286 & 13,805 & 17,468 & 19,843 & 21,506 \\
1993 & 20,622 & 19,932 & 25,046 & 25,781 & 27,875 \\
1998 & 18,896 & 11,802 & 19,729 & 23,092 & 28,618 \\
\hline & 22,947 & 15,187 & 19,482 & 20,834 & 24,045 \\
\hline
\end{tabular}

\section{Inequality patterns}

As was noted by other studies (Brandolini, 1999), the pattern of inequality in the distribution of income shows considerable fluctuations in the two decades considered here, although there is no particular trend. In a comparative context, while the level of income inequality in Italy in the 1980s was lower than in most other European countries, inequality rose in the nineties more than in most countries.

According to a recent OCDE report (2000), among the working-age population, income inequality increased during the past decade, while among the retirement-age population inequality decreased. The relative position of younger cohorts worsen relatively to older cohorts: children and 
young adults lost ground while all age groups over 40 improved their position ${ }^{4}$. Related to increases in income inequality, also relative poverty rose significantly.

The data (Figure 7) show that income dispersion measured by the squared coefficient of variation $\left(\mathrm{CV}^{2}\right)$ increased between 1977 and 1979, which marked the end of the fall that had characterized the seventies after the regulations implemented in the labor market, and the introduction of wage parity laws and wage indexation. After considerable growth in 1978-1979, income dispersion declined for most the 1980s and it remained quite stable during the $80 \mathrm{~s}^{5}$. Then inequality increased again in the 90s. The frequency of the data, initially annual and then biennial, makes it difficult to illustrate the link with the short-term business cycle. However, the relationship between inequality of income and the short-term business cycle seems to have been positive at least until the early 1990s: the dispersion of total incomes would tend to increase in periods of economic growth and decrease in periods of recession.

After the early 1990s, inequality started to rise and it became one of the highest in Europe. The link with the business cycle becomes more complicated and seems to be countercyclical ${ }^{6}$. The rise of income inequality in the 1990s is in fact contemporaneous with the recession of the early 1990s.

These phases are confirmed and discussed in other studies which have attributed the declining inequality to the compression of the wage structure in the eighties imposed by the egalitarian regulations obtained by the unions.

The increase in inequality in the 1990s was partly due to the institutional changes that characterized the labor market after the weakening of the unions. Performance-related premiums and bonuses were increasingly adopted in negotiations at the company level and weakened the egalitarian structure of earnings.

\footnotetext{
${ }^{4}$ A decomposition analysis of overall inequality suggests that the contribution of self-employment and capital income to inequality among the working-aged was more important than the contribution of gross earnings; furthermore, this contribution increased during the last ten years (Italy is the only country in which this feature has been found). This effect was entirely due to increased dispersion of self-employment and capital incomes while the changing share did not contribute to the increase in inequality. Public transfers were redistributed from children and older adults (those aged 51 to 65) to elderly age groups, particularly older senior citizens (OCDE, 2000).

${ }^{5}$ The peak in 1987 seems to be due more to dataset problems than to a real increase in income inequality.

${ }^{6}$ During recessions employers retain the most experienced workers as demand declines. The least skilled are laid off and experience income losses. Recoveries are accompanied by increased employment of the least experienced workers (Blank and Blinder, 1986). Differently from inequality in total income distribution, inequality in wages distribution seem therefore to decrease during recession.
} 


\section{Inequality in total household income in Italy 1977-1998 (CV2)}

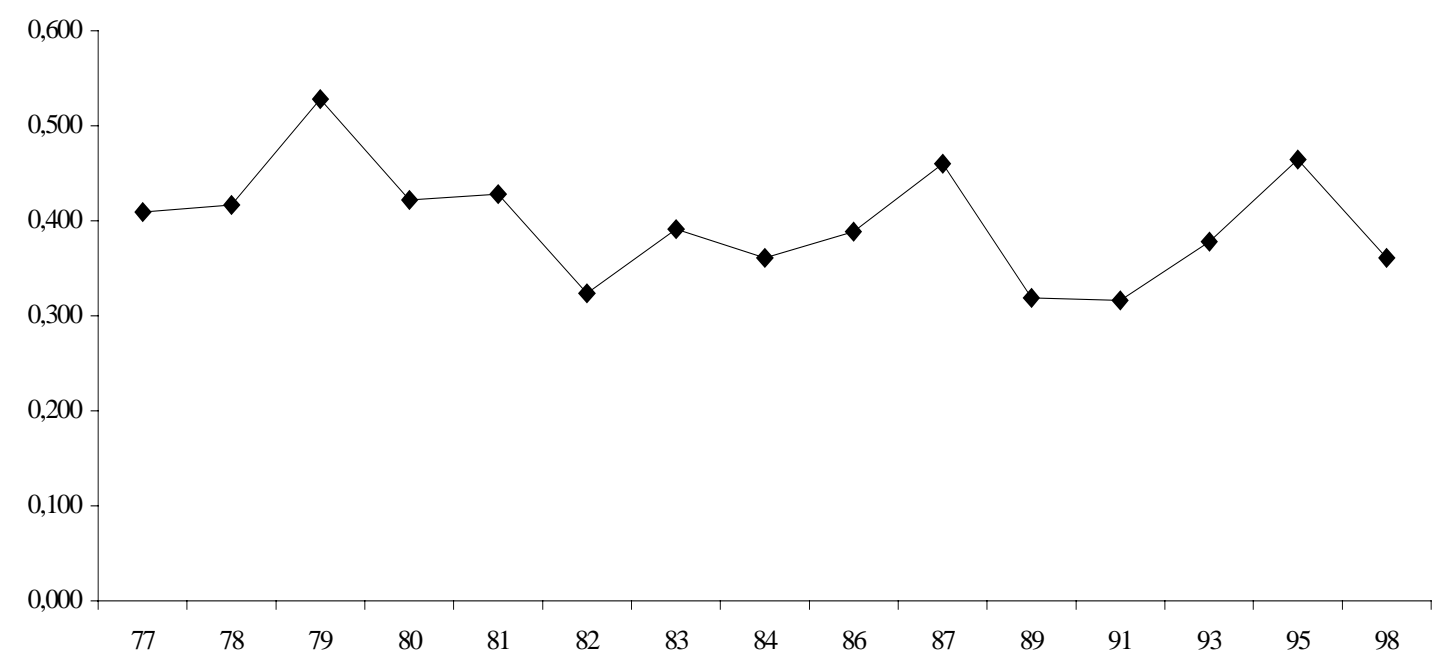

Recently there has been increasing attention to the patterns of European income and earnings inequality in this period, especially in comparison with the UK and US. Most analyses focusing on the pattern of income distribution in a comparative perspective argue that "institutions matter". Focusing on the distribution of earnings in Italy and the US, Manacorda (2000) analyzes the effect of wage indexation on inequality in Italy during the period 1977-1993. His analysis suggests that inequality would have increased throughout the 1980s and the 1990s at a rate similar to the one observed in the US, had the wage indexation system been inoperative ${ }^{7}$. He found, in particular, that the effects of wage indexation had been greater for female workers since their wages are, on average, lower than those of men and far more dispersed. Over time, the effect of wage indexation decreased for both men and women. This helps explain the increase in inequality in the nineties.

Other researches examining Italy in comparison with other countries of the European Union, have analyzed the effects of demographic structure on the evolution of inequality in Italy during the period 1977-1998. D'Alessio and Signorini (2000) have compared income inequality of households and individuals, showing how income inequality at individual level is greater than at households'

\footnotetext{
${ }^{7}$ Over the period of time considered, the equalizing effect of the indexation declines and disappears. In 1983, the Government reduced the value of wage indexation by approximately $15 \%$ to its 1977 level. And in 1986 the system was made semi-proportional by granting $100 \%$ coverage of a set minimum wage plus $25 \%$ coverage of the difference between the actual wage and the minimum wage.
} 
level and how the family redistributes resources between earners and non-earners and between earners of different income levels. The redistribution of income within the household compensates a high proportion of income inequality among individuals, but it declined during the last decade. Brandolini and D'Alessio (2001), examining the same period, analyzed the important demographic phenomena which characterized the Italian population in comparison with the rest of Europe (the size of the family declined, the number of young household heads decreased, while the number of single and lone parents increased). In spite of the relevance of these transformations, demographic variables did not seem to have a significant impact on the patterns of income inequality which seem to be explained mainly by significant regional differences.

In the next sections we will explore the relationship between the work of wives and husbands and income distribution across regions and over time.

\section{How wives' and husbands work contribute to household income inequality?}

To analyze the impact of the employment patterns of husbands and wives on family income distribution, we first consider the contribution of the spouses to household income and then to its dispersion. In order to eliminate short-term fluctuations, the following analysis is done only for three years: 1977, 1989 and 1998. Wives contribute less than husbands to household income (see Table 4, variables $S_{w}$ and $S_{h}$ ) in all the years, even if their contribution augments between 1977 and 1998. The growth of wives' contribution to household income is mainly concentrated in the first decade of the period (both in the North and in the South), while in the second decade the contribution increased only by 1-2 percentage points.

This pattern is the result of the effect of two different phenomena. On one hand, as we have discussed earlier, wives employment have continued to raise in the two decades considered (see Figure 5). On the other hand, while during the first decade (1977-1989) the difference between male and female earnings narrows, during the second decade (1989-1998) widen significantly (Manacorda, 2000). A similar pattern is observed analyzing wage differentials between husbands and wives. The family wage gap increased from the end of the eighties to the nineties (Table 3.A) ${ }^{8}$.

The proportion of low paid workers among husbands have declined until 1989 (from 5.4 to $2.7 \%$ ) and increased thereafter (from 2.7 to $8.9 \%$ ), while the proportion of low wage among wives

\footnotetext{
${ }^{8}$ Part-time employment is very limited in the Italian labor market (less than 10\%) and therefore the difference in the spouses' contribution to total household income cannot be explained by a difference in the hours worked by men and women.
} 
was much higher and it continued to decline during the all period (Brandolini, Cipollone and Sestito, 2000).

While wives contribution to household income increased, the contribution of men declined in all regions and particularly in the North. This is mainly attributed to the decline of husbands employment during the eighties and nineties (see Figure 6). The growth of household income is therefore due to the increase in wives contribution and the contribution of other sources of income. In fact, household income from other sources increased remarkably in the two decades (and this is again more evident in the North). The increasing importance of "other sources of income" for households income can be partly explained by the increasing proportion of adult children living with their parents. Recent Eurostat data show that differently from most European countries, the number of Italian adults children living with their family increased significantly and a large proportion of them are employed. Other incomes include also public transfers that, during the last decades, were directed mostly to the elderly at the expense of children and population in working age.

If the increased employment and earnings of wives have raised the average income of married couples, what have the effects been on income distribution?

In order to consider how men's and women's work affects income distribution, we first decompose $\mathrm{CV}^{2}$ by factors in order to analyze how wives' earnings, husbands' earnings and other sources of income contribute to total inequality and then we attempt to measure the impact of women's and men's work on income inequality, comparing inequality measures of the distribution of actual income with inequality measures calculated on income distribution less women's and men's earning. This is done in order to calculate the inequality that would occur if wives or husbands had no earnings.

Following the methodology for inequality decomposition by sources of income used in other studies (Shorrocks, 1982; Cancian and Reed, 1998; Cancian et al., 1992; Aaberge and Aslaksen, 2000; Jenkins, 1995), we consider only three sources of income: husband's earnings, wife's earnings and other sources of income (both from other components and non-labor income). The decomposition of the squared coefficient of variation of total household income $\left(C \mathrm{~V}^{2}{ }_{H H}\right)$ is achieved using the following formula:

$$
C V^{2}{ }_{H H}=S_{h}^{2} C V_{h}^{2}+S^{2}{ }_{w} C V^{2}{ }_{w}+S_{o}^{2} C V_{o}^{2}+2 \rho_{h w} S_{h} S_{w} C V_{h} C V_{w}+2 \rho_{h o} S_{h} S_{o} C V_{h} C V_{o}+2 \rho_{w o} S_{w} S_{o} C V_{w} C V_{o}
$$


where $C V_{i}$ is the coefficient of variation of the $i$-th source of income, $\rho_{i j}$ is the coefficient of correlation between the $i$-th and the $j$-th sources of income and $S_{i}$ is the income share of the $i$-th source of income (computed as the ratio between the mean value of the source and the mean value of household income). $H H$ refers to the households, $h$ to the husbands, $w$ to the wives and $o$ to other sources of income (calculated as the difference between total family income and spouses' earnings).

Inequality in the distribution of household income is therefore obtained as a weighted average of the inequality of each component's income (where the weights are the shares of total household income corresponding to each component) and the correlation among the different sources.

Table 4 shows the squared coefficient of variation of total household income. For all married couples inequality declined and then increased again after 1989 . The $\mathrm{CV}^{2}$ of wives earnings is much higher than the $\mathrm{CV}^{2}$ of all other sources of income (husbands' and "other"), but it declined during the entire period while the coefficient of variation of husbands earnings increased considerably between 1989 and 1998.

The decline in inequality of wives earnings is mainly attributable to the increased employment (far fewer wives had zero earnings in 1998 than in 1977). And in fact the coefficient of variation of the earnings computed only for working wives (which excludes the zero earners) increased over the period from 0.250 to 0.386 . This means that the decline in $\mathrm{CV}^{2}{ }_{\mathrm{w}}$ is due to the "employment" effect, rather than to a decline in the inequality in actual female labor income distribution. The distribution of "other incomes" became more equal during the last two decades.

When we consider separately the North and the South, we find that among Northern households inequality is lower than among Southern households. Moreover, while dispersion in Northern households income shows a stronger downward trend in the 80s, family income inequality in the South increased, especially during the nineties.

In the North, the effect of employment of husbands and wives is fairly similar to the one described for the whole country. On the contrary, in the South inequality in (all) wives' earnings is quite remarkable (almost three times the dispersion among Northern wives). The large decline in the inequality of wives' earnings among all women in the period 1977-1989 reflects both an increased percentage of women working and a more equal distribution among working wives. And in fact, $\mathrm{CV}^{2}{ }_{\text {w }}$ of working wives' earnings declined from 0.423 to 0.176 during the eighties. On the contrary, the increase in $\mathrm{CV}^{2}$ wall between 1989 and 1998 is the result of an increased dispersion in working women's earnings.

At the same time, in the Southern regions $\mathrm{CV}^{2}$ of husbands' earnings dispersion declined 
from 0.732 to 0.489 during the eighties and increased to 0.867 during the nineties. This is due both to the increase in inequality in the distribution of earnings among working husbands, and to the decline in the number of working husbands (that produced an increase in the zeros in the distribution).

Finally while "other incomes" inequality continued to decline remarkably in the North, in the South it increased in the eighties but declined again in the nineties returning to the previous value.

Table 4

Main factors in $\mathbf{C V}^{2} \mathrm{HH}$ decomposition

\begin{tabular}{|c|c|c|c|}
\hline & 1977 & 1989 & 1998 \\
\hline & \multicolumn{3}{|c|}{ Italy } \\
\hline $\mathrm{CV}_{\mathrm{HH}}^{2}$ & 0.409 & 0.319 & 0.361 \\
\hline $\mathrm{CV}_{\mathrm{h} \text { all }}^{2}$ & 0.641 & 0.533 & 0.759 \\
\hline $\mathrm{CV}^{2}{ }_{\mathrm{h} \text { working }}$ & 0.376 & 0.302 & 0.376 \\
\hline $\mathrm{CV}^{2}{ }_{\mathrm{w} \text { all }}$ & 3.855 & 2.180 & 2.108 \\
\hline $\mathrm{CV}^{2}{ }_{\text {w working }}$ & 0.250 & 0.165 & 0.386 \\
\hline $\mathrm{CV}_{\mathrm{o}}^{2}$ & 1.761 & 1.486 & 1.268 \\
\hline $\mathrm{S}_{\mathrm{h}}$ & 56.2 & 51.6 & 43.8 \\
\hline$S_{w}$ & 10.8 & 16.4 & 17.5 \\
\hline \multirow[t]{2}{*}{$\rho_{\mathrm{hw}}$} & 0.155 & 0.135 & 0.214 \\
\hline & \multicolumn{3}{|c|}{ North } \\
\hline $\mathrm{CV}^{2}{ }_{\mathrm{HH}}$ & 0.353 & 0.258 & 0.278 \\
\hline $\mathrm{CV}_{\mathrm{h} \text { all }}^{2}$ & 0.544 & 0.551 & 0.702 \\
\hline $\mathrm{CV}^{2}{ }_{\mathrm{h} \text { working }}$ & 0.318 & 0.297 & 0.334 \\
\hline $\mathrm{CV}^{2}$ w all & 2.697 & 1.518 & 1.388 \\
\hline $\mathrm{CV}^{2}$ w working & 0.189 & 0.159 & 0.301 \\
\hline $\mathrm{CV}_{\mathrm{o}}{ }^{\circ}$ & 2.015 & 1.296 & 1.114 \\
\hline $\mathrm{S}_{\mathrm{h}}$ & 57.4 & 48.6 & 41.1 \\
\hline$S_{w}$ & 13.0 & 18.2 & 19.1 \\
\hline \multirow[t]{2}{*}{$\rho_{\mathrm{hw}}$} & 0.131 & 0.115 & 0.259 \\
\hline & \multicolumn{3}{|c|}{ South } \\
\hline $\mathrm{CV}^{2}{ }_{\mathrm{HH}}$ & 0.434 & 0.373 & 0.452 \\
\hline $\mathrm{CV}_{\mathrm{h} \text { all }}^{2}$ & 0.732 & 0.487 & 0.867 \\
\hline $\mathrm{CV}^{2}{ }_{\mathrm{h} \text { working }}$ & 0.460 & 0.282 & 0.439 \\
\hline $\mathrm{CV}^{2}$ w all & 8.336 & 3.620 & 4.033 \\
\hline $\mathrm{CV}^{2}{ }_{\mathrm{w} \text { working }}$ & 0.423 & 0.176 & 0.589 \\
\hline $\mathrm{CV}_{\mathrm{o}}^{2}$ & 1.568 & 1.818 & 1.594 \\
\hline $\mathrm{S}_{\mathrm{h}}$ & 57.9 & 57.5 & 49.3 \\
\hline$S_{w}$ & 7.0 & 13.6 & 15.1 \\
\hline$\rho_{\mathrm{hw}}$ & 0.132 & 0.138 & 0.010 \\
\hline
\end{tabular}




\section{Simulations}

Now we attempt to measure the impact of women's work on income inequality, comparing inequality measurements of actual income distribution with inequality calculated on income distribution less wives earnings (Table 5, Counterfactual 1). This implies to calculate the inequality in household income distribution that would occur if wives had no earnings. This is obviously a considerable approximation of the impact of women's work on income distribution because it does not take into account the fact that without their wives' earnings, husbands' labor supply would possibly have been greater and household savings lower, and therefore the households' capital income would have been lower too. However, most analyses of the labor supply of husbands and wives in Italy have shown that while the flexibility of the labor supply by wives is quite high, the labor supply of husbands is unresponsive to income and wage changes (Colombino and Del Boca, 1990).

These measurements, compared with the measurements observed, can give a picture of how women's earnings affect income distribution.

Measures of inequality of total income are higher than measures of inequality calculated using total income less women's earnings in all years considered but in South in 1989.

These measures indicate that total income distribution without women's labor income would have been more unequal, and therefore that wives' work had an equalizing impact on income distribution. The equalizing effect is much stronger in the Northern regions, where female employment is in fact higher, especially in the low-middle quintile groups, and during the nineties.

Using the same methodology we also want to simulate the effect of men's work on income inequality in household income distribution (Table 5, Counterfactual 2). Measures of inequality of family income are much higher than measure of inequality calculated using total income less men earnings.

Another important source of income is represented by "other incomes", partly due to the adults children work and to public transfers. We calculate inequality in household income distribution that would occur if households had no income from other sources besides husbands and wives earnings. In the third column of Table 5 we report the results of this simulation. As we can see, income distribution without other incomes would have been about the same when considering Italy, in the last two decades, but would have been different when considering the two different regional areas. Without other incomes, distribution would have been more equal in the North (except in 1977), and more unequal in the South. This indicates the different nature of "other 
incomes" in the two areas: in the North adult children income seems to be more relevant, while in the South public transfers appear to be more important.

Table 5

\begin{tabular}{|c|c|c|c|c|}
\hline \multicolumn{5}{|c|}{$\begin{array}{l}\text { Inequality in counterfactual distributions - } \\
\mathrm{CV}^{2} \text { of total household net income }\end{array}$} \\
\hline & \multirow{2}{*}{ True } & Counterfactual 1 & Counterfactual 2 & Counterfactual 3 \\
\hline & & If no women work & If no men work & If no other incomes \\
\hline & \multicolumn{4}{|c|}{ Italy } \\
\hline 1977 & 0.409 & 0.439 & 1.161 & 0.393 \\
\hline 1989 & 0.319 & 0.356 & 0.844 & 0.319 \\
\hline \multirow[t]{2}{*}{1998} & 0.361 & 0.399 & 0.753 & 0.363 \\
\hline & \multicolumn{4}{|c|}{ North } \\
\hline 1977 & 0.353 & 0.405 & 1.099 & 0.441 \\
\hline 1989 & 0.258 & 0.328 & 0.616 & 0.239 \\
\hline \multirow[t]{2}{*}{1998} & 0.278 & 0.344 & 0.545 & 0.250 \\
\hline & \multicolumn{4}{|c|}{ South } \\
\hline 1977 & 0.434 & 0.436 & 1.265 & 0.445 \\
\hline 1989 & 0.373 & 0.367 & 1.228 & 0.399 \\
\hline 1998 & 0.452 & 0.462 & 1.138 & 0.476 \\
\hline
\end{tabular}

Another relevant question concerns the regional differences: wives and husbands work much less in Southern households than in Northern households. How family income would be distributed in the South if Southern wives and husbands' earnings would be distributed in the same way than Northern wives and husbands earnings? Table 6 shows that income inequality would decrease even if it would remain much higher than in the North.

Table 6

\begin{tabular}{|c|c|c|c|}
\hline & \multicolumn{3}{|c|}{$\begin{array}{l}\text { Inequality in counterfactual distributions - } \\
\mathrm{CV}^{2} \text { of total household net income }\end{array}$} \\
\hline & \multirow[b]{2}{*}{ True } & Counterfactual 4 & Counterfactual 5 \\
\hline & & $\begin{array}{l}C V^{2} \text { of wives in the } \\
\text { South as in the North }\end{array}$ & $\begin{array}{l}C V^{2} \text { of husbands in the } \\
\text { South as in the North }\end{array}$ \\
\hline & \multicolumn{3}{|c|}{ South } \\
\hline 1977 & 0.434 & 0.413 & 0.403 \\
\hline 1989 & 0.373 & 0.344 & 0.383 \\
\hline 1998 & 0.452 & 0.408 & 0.433 \\
\hline
\end{tabular}




\section{Conclusions}

The analysis of the relationship between employment patterns and income inequality is important for determining the consequences of changes in the composition of the labor force and in transfer policies. In Italy income inequality declined in the eighties and increased in the nineties. There has been growing concern that recent changes in the pattern of employment and wages of married women would cause wives' earnings to be less equalizing, or even that they might increase inequality.

In this paper we use micro data of the Historical Archive of the Bank of Italy Survey of Household's Income and Wealth (SHIW), a repeated cross-sectional survey that covers the period 1977-1998. The Bank of Italy data show that in the regions where women's employment is higher, household income is more equally distributed. This relationship becomes stronger over time. Important differences are noticeable across regions. Among Northern households, inequality of household income shows a downward trend, while in the South family income inequality rose, especially during the nineties. In the North, inequality is less pronounced than in the South and declined until 1998.

Our results show that the increase in the employment of women during the period of observation had the effect of reducing inequality in family incomes. The decline in the dispersion of wives' earnings appear to have been more important than the increased correlation in the earnings of the spouses. Especially since the mid-nineties, wives' earnings have reduced inequality, in the sense that the distribution of income would have been less equal in their absence. The equalizing impact of wives' work on income inequality has become increasingly important over time and has been greater among Northern households.

These results can be interpreted in the light of our previous analysis (Del Boca, Locatelli and Pasqua, 2000) in which an added worker effect is found in households in which the role of women in the labor market has been long accepted and consolidated and in areas where more opportunities are available in terms of working hours as well as childcare facilities. Since these factors are more widespread in the Northern areas of Italy, we would expect there a stronger equalizing effect (since the employment of wives in lower income families reduces inequality). Consistently with these results, the reduction in the dispersion of wives' earnings determined by the increased employment seem to have contributed to offset, especially in the Northern areas, the increases in the dispersion of husbands earnings and the increased correlation in the earnings of the spouses.

These results indicate that policies oriented to encourage labor supply by increasing the number of jobs available (such as fixed term contracts or training programs) have more impact on 
married women employment in the North where women labor supply are more responsive to changes in the labor market than in the South where women seem to be more constrained by the lack of social services. Therefore, policies more relevant to encourage Southern women to work should include child care opportunities.

The inequality decompositions performed in this paper are suggestive of the changes in some of the sources of household income distribution that have been observed in Italy recently, but of course do not offer an explanation for these changes. One possible explanation for the increase in the employment rate of wives and the decrease in the employment rate of husbands is the pattern of male/female wage differentials. In order to determine whether this explanation is plausible, a behavioural model of household decision-making should be constructed and estimated. With parameter estimates from such a model, and with unbiased estimates of male and female wage offer distributions, implied distributions of earnings and household income can be constructed and compared with those observed over time. This will allow us to determine the proportion of household income inequality that can be explained by changes in gender-specific wage offer distributions. By focusing on intra-household behavior, we will also be able to explore the consequences of these changes for inequality in intra-household utility levels. This last point seems to be at least as important policy issue as we have explicitly addressed in the current paper, but one that is very much under-researched to this point. 


\section{Bibliography}

Alesina A. and Rodrick D. (1992), “ Distribution, Political Conflict, and Economic Growth: A Simple Theory and Some Empirical Evidence", in Cukierman A., Hercowitz Z. and Leiderman L. (eds.), Political economy, growth, and business cycles, Cambridge and London MIT Press, p. 23-50

Aaberge R. and Aslaksen I. (2000), "Decomposition of the Gini Coefficient Revisited: the Effects of Wives' Earnings on Family Income Inequality", mimeo

Banca d'Italia (2000), Indagine sui bilanci delle famiglie italiane, CD-ROM Versione 1.1, October.

Barrere -Maurisson M., Battagliola F. and Daune R.A. (1985), “The course of women's career and family life" in Finnegan R.B. and Gallie D. (eds.), New Approaches to Economic Life, Manchester University Press, p. 431-458

Benabou R.(1996), “Inequality and Growth”, NBER Macroeconomics Annual 1996, p. 11-92

Betson D. and van der Gaag J. (1984), "Working Married Women and the Distribution of Income" Journal of Human Resources, vol. 19, p. 532-543

Blackburn, M. and Bloom D. (1994), "Changes in the structure of family income inequality in the United States and other industrial nations during the 1980s", LIS working Paper n.118

Blank R. and Blinder A. (1986), "Macroeconomics, Income Distribution and poverty" in Danziger S. and Weinberg D. (eds.), Fighting Poverty, Harvard University Press, Cambridge US

Brandolini A. (1999), “The Distribution of Personal Income in Post-War Italy: Source Description, Data Quality, and the Time Pattern of Income Inequality", Giornale degli Economisti ed Annali di Economia, vol. 85, p. 183-201

Brandolini A. and D’Alessio G. (2001), "Household Structure and Income Distribution in Italy", in Del Boca and Repetto (eds.), Women Work, the Family and Social Policy in Italy, Peter Lang

Brandolini A., Cipollone P. and Sestito P. (2000), "Earnings Dispersion, Low Pay and Household Poverty in Italy, 1977-1998”, Bank of Italy, Rome

Cancian M, Danziger S. and Gottschalk P. (1992), "Working Wives and Family Income Inequality among Married Couples", in Danziger S. and Gottschall P. (eds.), Uneven Tides - Rising Inequality in America, NY, Russell Sage Foundation 
Cancian M. and Reed D. (1998), “Assessing the Effects of Wives' Earnings on Family Income Inequality", The Review of Economics and Statistics, vol. 80, p. 73-79

Chiuri (2000) "Quality and Demand of Childcare and Female Labour Supply in Italy", Labour, vol.14(1), p. $97-118$

Colombino U. and Del Boca D. (1990), “The effect of taxes on Labour Supply in Italy", Journal of Human Resources, vol. 25, p.35-47

D’Alessio, G. and Signorini L. F. (2000), "Disuguaglianza dei redditi individuali e ruolo della famiglia in Italia", Banca d'Italia, Temi di discussione, No. 390, December

Del Boca D. (2001), "Participation and Fertility of Married Women in Italy", forthcoming Journal of Population Economics

Del Boca D., Locatelli M. and Pasqua S. (2000), "Employment Decision of Married Women: Evidence and Explanations", Labour, vol.14 (1), p. 35-52

Del Boca D., Locatelli M. and Pasqua S. (2001), "Earnings and Employment of Husbands and Wives" in Del Boca and Repetto (eds.), Women Work, the Family and Social Policy in Italy, Peter Lang

Ercolani M. G. and Jenkins S. P. (1999), "The Labour Force Participation of Women Married to Unemployed Men: Is There an Added Worker Effect?", mimeo

ISTAT (1998), "La distribuzione quantitativa del reddito in Italia nelle indagini sui bilanci di famiglia. Anno 1996", Informazioni, No. 62

Jenkins, S. (1995), “Accounting for Inequality Trends: Decomposition Analyses for the UK, 197186", Economica, vol. 62, p. 29-63

Karoly L.A. and Burtless G. (1995), “The Effects of Rising Earnings Inequality on the Distribution of U.S. Income", Demography, vol. 32, p. 379-406

Lam, D. (1997), "Demographic Variables and Income Inequality", in Rosenzweig M. R. and Stark O. (eds.), Handbook of Population and Family Economics, p. 1015-1059, Amsterdam, Elsevier Science

Lundberg S. (1985), “The Added Worker Effect”, Journal of Labor Economics, vol. 3, p. 11-37

Manacorda M. (2000), “The Fall and Rise of Earnings Inequality in Italy”, UC Berkeley Center for Labor Economics 
Molho I. and Elias P. (1984), "A Study of Regional Trends in the Labor Force Participation of Married Women in the UK", Applied Economics, vol. 16 (2), p. 163-174

Neumark D. and Postlewhite A (1995), “Relative income concern and the rise in Married women's Employment”, National Bureau of Economic Research Working Paper N. 5044

OECD (1996), "Earnings Inequality, Low Paid Employment and Earnings Mobility", Employment Oulook, p. 59-108, Paris

OECD (1999), Employment Outlook, Paris

OECD (2000), "Trends and Driving Factors in Income Distribution and Poverty in the OECD area", Labour Market and Social Policy Occasional paper n. 42 Paris

Pasqua S. (2001), “Women’s Work and Income Inequality in European countries”, mimeo

Rossetti R. Tanda P.(2000), "Human Capital, Wages and family Interactions”, Labour, vol.14(1), p. 5-34

Shorrocks A. F. (1982), "Inequality Decomposition by Factor Components”, Econometrica, vol. 50, p. $193-211$ 


\section{Appendix}

\section{Table AI}

\begin{tabular}{|c|c|c|c|c|c|c|c|c|c|c|c|c|c|c|c|}
\hline \multicolumn{16}{|c|}{ Descriptive statistics } \\
\hline & 1977 & 1978 & 1979 & 1980 & 1981 & 1982 & 1983 & 1984 & 1986 & 1987 & 1989 & 1991 & 1993 & 1995 & 1998 \\
\hline \multicolumn{16}{|l|}{ Area $(\%)$} \\
\hline North & 50.9 & 49.6 & 48.7 & 46.6 & 41.8 & 41.1 & 39.9 & 39.1 & 41.0 & 43.5 & 37.9 & 39.6 & 40.9 & 42.3 & 40.2 \\
\hline Center & 19.1 & 20.9 & 19.4 & 19.8 & 22.1 & 23.8 & 24.9 & 24.3 & 23.0 & 19.3 & 21.9 & 19.3 & 21.6 & 21.0 & 21.5 \\
\hline South & 30.0 & 29.5 & 31.9 & 33.6 & 36.1 & 35.1 & 35.2 & 36.6 & 36.0 & 37.2 & 40.2 & 41.1 & 37.5 & 36.7 & 38.3 \\
\hline \multicolumn{16}{|c|}{ Husband education (\%) } \\
\hline$<$ secondary & 81.1 & 76.5 & 76.7 & 73.9 & 74.5 & 71.8 & 72.0 & 68.2 & 68.4 & 61.3 & 63.3 & 65.5 & 65.7 & 61.4 & 55.0 \\
\hline Secondary & 13.1 & 16.6 & 14.6 & 17.9 & 19.3 & 20.3 & 20.0 & 22.6 & 24.2 & 25.9 & 27.6 & 25.9 & 26.2 & 30.0 & 35.7 \\
\hline$>$ secondary & 5.8 & 6.9 & 8.7 & 8.2 & 6.2 & 7.9 & 8.0 & 9.2 & 7.4 & 12.8 & 9.1 & 8.6 & 8.1 & 8.6 & 9.3 \\
\hline \multicolumn{16}{|l|}{ Wife education (\%) } \\
\hline$<$ secondary & 77.8 & 71.1 & 69.6 & 64.9 & 68.3 & 65.5 & 63.8 & 56.8 & 58.8 & 50.7 & 67.3 & 68.3 & 68.5 & 64.0 & 56.8 \\
\hline Secondary & 16.1 & 20.7 & 23.1 & 27.6 & 24.1 & 26.3 & 26.2 & 30.4 & 31.4 & 34.5 & 26.0 & 25.4 & 24.5 & 28.5 & 33.9 \\
\hline$>$ secondary & 6.1 & 8.3 & 7.3 & 7.5 & 7.6 & 8.2 & 10.0 & 12.8 & 9.8 & 15.2 & 6.7 & 6.3 & 7.0 & 7.5 & 9.3 \\
\hline Husband age & 48.3 & 48.2 & 47.9 & 48.3 & 47.5 & 48.1 & 48.4 & 46.0 & 45.8 & 45.7 & 45.6 & 46.5 & 46.8 & 47.0 & 47.5 \\
\hline Wife age & 44.1 & 43.9 & 43.7 & 44.2 & 43.3 & 43.9 & 44.2 & 41.9 & 41.8 & 41.7 & 41.8 & 42.7 & 42.9 & 43.2 & 43.7 \\
\hline Husband working & 83,8 & 86,5 & 85,4 & 82,8 & 82,4 & 85,2 & 82,9 & 88,5 & 87,0 & 88,5 & 84,8 & 82,3 & 80,0 & 78,2 & 77,5 \\
\hline Wives working & 25,7 & 30,5 & 32,8 & 32,4 & 29,6 & 31,7 & 31,1 & 35,1 & 35,6 & 35,6 & 36,6 & 37,0 & 40,2 & 41,5 & 44,3 \\
\hline
\end{tabular}


Table A.2

Mean of household income sources

(thousands - in constant 1998 lira)

\begin{tabular}{|c|c|c|c|c|c|c|}
\hline & 1977 & 1980 & 1984 & 1989 & 1993 & 1998 \\
\hline & \multicolumn{6}{|c|}{ Italy } \\
\hline Total household income & 40,145 & 45,246 & 46,826 & 53,609 & 53,290 & 55,192 \\
\hline Husband's earnings & 22,564 & 23,796 & 26,704 & 27,677 & 24,651 & 24,201 \\
\hline Wife's earnings & 4,321 & 5,921 & 6,727 & 8,787 & 8,704 & 9,663 \\
\hline \multirow[t]{2}{*}{ Other sources } & 13,278 & 15,528 & 13,395 & 17,144 & 19,936 & 21,328 \\
\hline & \multicolumn{6}{|c|}{ North } \\
\hline Total household income & 45,010 & 47,193 & 50,294 & 61,742 & 60,750 & 65,364 \\
\hline Husband's earnings & 25,826 & 25,764 & 28,131 & 30,029 & 26,377 & 26,866 \\
\hline Wife's earnings & 5,851 & 7,366 & 7,547 & 11,250 & 10,498 & 12,472 \\
\hline \multirow[t]{2}{*}{ Other sources } & 13,333 & 14,062 & 14,615 & 20,462 & 23,875 & 26,025 \\
\hline & \multicolumn{6}{|c|}{ South } \\
\hline Total household income & 31,307 & 33,451 & 40,649 & 44,976 & 42,323 & 43,035 \\
\hline Husband's earnings & 18.137 & 19,152 & 23,641 & 25,865 & 21,537 & 21,223 \\
\hline Wife's earnings & 2,185 & 3,201 & 5,221 & 6,127 & 6,445 & 6,513 \\
\hline Other sources & 10,984 & 11,097 & 11,787 & 12,984 & 14,340 & 15,299 \\
\hline
\end{tabular}


Table A.3

Gender labor income gap

(average working wives earnings as a percentage of average working husbands earnings)

\begin{tabular}{lccc}
\hline Year & Italy & North & South \\
\hline 1977 & 62.4 & 60.1 & 66.7 \\
1978 & 64.1 & 61.1 & 69.9 \\
1979 & 61.1 & 61.3 & 62.4 \\
1980 & 63.6 & 62.8 & 63.2 \\
1981 & 65.4 & 61.7 & 71.1 \\
1982 & 63.9 & 63.5 & 61.9 \\
1983 & 64.0 & 60.2 & 67.0 \\
1984 & 63.6 & 60.9 & 66.2 \\
1986 & 65.1 & 61.2 & 67.6 \\
1987 & 61.3 & 56.3 & 67.7 \\
1989 & 73.6 & 68.0 & 80.2 \\
1991 & 72.9 & 69.6 & 78.7 \\
1993 & 70.6 & 66.9 & 79.4 \\
1995 & 68.6 & 64.3 & 76.0 \\
1998 & 70.1 & 66.8 & 74.9 \\
\hline
\end{tabular}




\section{IZA Discussion Papers}

$\begin{array}{ll}\text { No. } & \text { Author(s) } \\ 472 & \begin{array}{l}\text { R. Foellmi } \\ \text { J. Zweimüller }\end{array} \\ 473 & \text { J. C. van Ours } \\ 474 & \text { J. T. Addison } \\ & \begin{array}{l}\text { L. Bellmann } \\ \text { A. Kölling }\end{array} \\ 475 & \begin{array}{l}\text { Z. Hercowitz } \\ \text { E. Yashiv }\end{array} \\ 476 & \begin{array}{l}\text { W. A. Cornelius } \\ \text { T. Tsuda }\end{array}\end{array}$

$477 \quad$ M. A. Clark

D. A. Jaeger

H. Gersbach

A. Schniewind

\section{J. T. Addison}

C. R. Belfield

G. Saint-Paul

E. Schlicht

P. Kuhn

C. Weinberger

H. Rapoport

A. Weiss

J. H. Bishop

L. Woessmann

L. Woessmann M. R. West

A. L. Booth M. L. Bryan

R. L. Lumsdaine

E. S. Prasad
A. Ciccone
G. Peri
D. Del Boca
S. Pasqua

Title

Area

Date

Structural Change and the Kaldor Facts of

3

$04 / 02$

Economic Growth

A pint a day raises a man's pay, but smoking

5

$04 / 02$ blows that gain away

Unions, Works Councils and Plant Closings in

3

04/02

Germany
A Macroeconomic Experiment in Mass Immigration
Labor Market Incorporation of Immigrants in Japan and the United States: A Comparative Analysis

1

04/02

Natives, the Foreign-Born and High School

Equivalents: New Evidence on the Returns to the GED

Uneven Technical Progress and Unemployment 3

Unions and Employment Growth: The One

04/02

Constant?

The Complexity of Economic Policy:

04/02

I. Restricted Local Optima in Tax Policy Design

Hiring Standards and Market Clearing

$04 / 02$

Leadership Skills and Wages

04/02

In-Group Cooperation in a Hostile Environment: An Economic Perspective on Some Aspects of Jewish Life in (Pre-Modern) Diaspora

Institutional Effects in a Simple Model of

Educational Production

$04 / 02$

Class-Size Effects in School Systems Around the World: Evidence from Between-Grade Variation in TIMSS

Who pays for General Training? New Evidence

Identifying the Common Component of

A New Approach

Identifying Human Capital Externalities:

Theory with an Application to US Cities

Employment Patterns of Husbands and Wives and Family Income Distribution in Italy (19771998) 